\title{
Front Matter: Volume 10162
}

, "Front Matter: Volume 10162," Proc. SPIE 10162, Bioinspiration, Biomimetics, and Bioreplication 2017, 1016201 (7 May 2017); doi: $10.1117 / 12.2280217$

EDIE SPIE Smart Structures and Materials + Nondestructive Evaluation and Health Monitoring, 2017, Portland, Oregon, United States 


\title{
PROCEEDINGS OF SPIE
}

\section{Bioinspiration, Biomimetics, and Bioreplication 2017}

\author{
Mato Knez \\ Akhlesh Lakhtakia \\ Raúl J. Martín-Palma \\ Editors
}

\section{6-27 March 2017 \\ Portland, Oregon, United States}

Sponsored by

SPIE

Co-sponsored by

Optical Society of Southern California (United States)

Cooperating Organizations

Jet Propulsion Laboratory (United States)

Published by

SPIE 
The papers in this volume were part of the technical conference cited on the cover and title page. Papers were selected and subject to review by the editors and conference program committee. Some conference presentations may not be available for publication. Additional papers and presentation recordings may be available online in the SPIE Digital Library at SPIEDigitallibrary.org.

The papers reflect the work and thoughts of the authors and are published herein as submitted. The publisher is not responsible for the validity of the information or for any outcomes resulting from reliance thereon.

Please use the following format to cite material from these proceedings:

Author(s), "Title of Paper," in Bioinspiration, Biomimetics, and Bioreplication 2017, edited by Mato Knez, Akhlesh Lakhtakia, Raúl J. Martín-Palma, Proceedings of SPIE Vol. 10162 (SPIE, Bellingham, WA, 2017) Seven-digit Article CID Number.

ISSN: 0277-786X

ISSN: 1996-756X (electronic)

ISBN: 9781510608092

ISBN: 9781510608108 (electronic)

Published by

SPIE

P.O. Box 10, Bellingham, Washington 98227-0010 USA

Telephone +1 3606763290 (Pacific Time) · Fax +1 3606471445

SPIE.org

Copyright (c) 2017, Society of Photo-Optical Instrumentation Engineers.

Copying of material in this book for internal or personal use, or for the internal or personal use of specific clients, beyond the fair use provisions granted by the U.S. Copyright Law is authorized by SPIE subject to payment of copying fees. The Transactional Reporting Service base fee for this volume is $\$ 18.00$ per article (or portion thereof), which should be paid directly to the Copyright Clearance Center (CCC), 222 Rosewood Drive, Danvers, MA 01923. Payment may also be made electronically through CCC Online at copyright.com. Other copying for republication, resale, advertising or promotion, or any form of systematic or multiple reproduction of any material in this book is prohibited except with permission in writing from the publisher. The CCC fee code is 0277-786X/17/\$18.00.

Printed in the United States of America.

Publication of record for individual papers is online in the SPIE Digital Library.

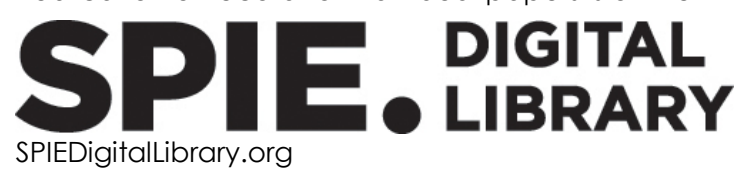

Paper Numbering: Proceedings of SPIE follow an e-First publication model. A unique citation identifier (CID) number is assigned to each article at the time of publication. Utilization of CIDs allows articles to be fully citable as soon as they are published online, and connects the same identifier to all online and print versions of the publication. SPIE uses a seven-digit CID article numbering system structured as follows:

- The first five digits correspond to the SPIE volume number.

- The last two digits indicate publication order within the volume using a Base 36 numbering system employing both numerals and letters. These two-number sets start with 00, 01, 02, 03, 04, 05, 06, 07, 08, 09, OA, OB ... OZ, followed by 10-1Z, 20-2Z, etc. The CID Number appears on each page of the manuscript. 


\title{
Contents
}

\author{
$\checkmark$ Authors \\ vii Conference Committee
}

\section{SESSION 1 FLIGHT}

1016203 Foldable drones: from biology to technology (Invited Paper) [10162-1]

1016204 A parametric study on a bio-inspired continuously morphing trailing edge [10162-2]

1016205 Computational analysis of flapping two different airfoils at laminar flow for flapping wing micro aerial vehicle [10162-3]

\section{SESSION 2 MECHANOBIOLOGY AND DRUG DELIVERY}

1016206 Can a robot grow? Plants give us the answer (Invited Paper) [10162-4]

1016207 Design and evaluation of a wasp-inspired steerable needle (1st Place H. Don Wolpert Best Student Paper Award) [10162-5]

1016208 Mosquito inspired medical needles [10162-6]

$101620 \mathrm{~A}$ Liposomes: bio-inspired nano-containers for physically triggered targeted drug delivery (2nd Place H. Don Wolpert Best Student Paper Award) [10162-8]

\section{SESSION 3 MATERIALS}

10162 OD Biomimetic reactions in conducting polymers for artificial muscles: sensing working conditions [10162-11]

$101620 G$ MEMS scale artificial hair cell sensors inspired by the cochlear amplifier effect (3rd Place H. Don Wolpert Best Student Paper Award) [10162-14]

\section{SESSION 4 CHARACTERIZATION}

10162 0 A thin polymer membrane 'NanoSuit' allows living organisms to survive in the harsh conditions of electron microscopy (Invited Paper) [10162-16]

10162 OK Three-dimensional imaging of human brain tissues using absorption-contrast highresolution X-ray tomography [10162-17] 


\section{SESSION 5 MECHANISMS AND MODELS}

$10162 \mathrm{ON}$ Comparison of live stimuli and 3D printed replicas: preference tests for zebrafish [10162-20]

1016200 Investigation of propulsive characteristics due to traveling waves in continuous finite media [10162-21]

$10162 \mathrm{OP}$ Zebrafish response to live predator and biologically-inspired robot in a circular arena [10162-22]

\section{SESSION 6 FUNCTIONAL SURFACES}

10162 OT Design of bioinspired chirped reflectors using a genetic algorithm [10162-26]

10162 OU Morpho-colored flexible film fabricated by simple mass-production method [10162-27]

10162 OV Bioinspired multicontrollable metasurfaces and metamaterials for terahertz applications [10162-28]

\section{POSTER SESSION}

10162 0X Robotic chemotaxis controller [10162-32]

1016210 Sensitive photoreceiver based on carbon nanotube/tobacco cell composite material [10162-36] 


\section{Authors}

Numbers in the index correspond to the last two digits of the seven-digit citation identifier (CID) article numbering system used in Proceedings of SPIE. The first five digits reflect the volume number. Base 36 numbering is employed for the last two digits and indicates the order of articles within the volume. Numbers start with 00, 01, 02, 03, 04, 05, 06, 07, 08, 09, 0A, 0B...0Z, followed by 10-1Z, 20-2Z, etc.

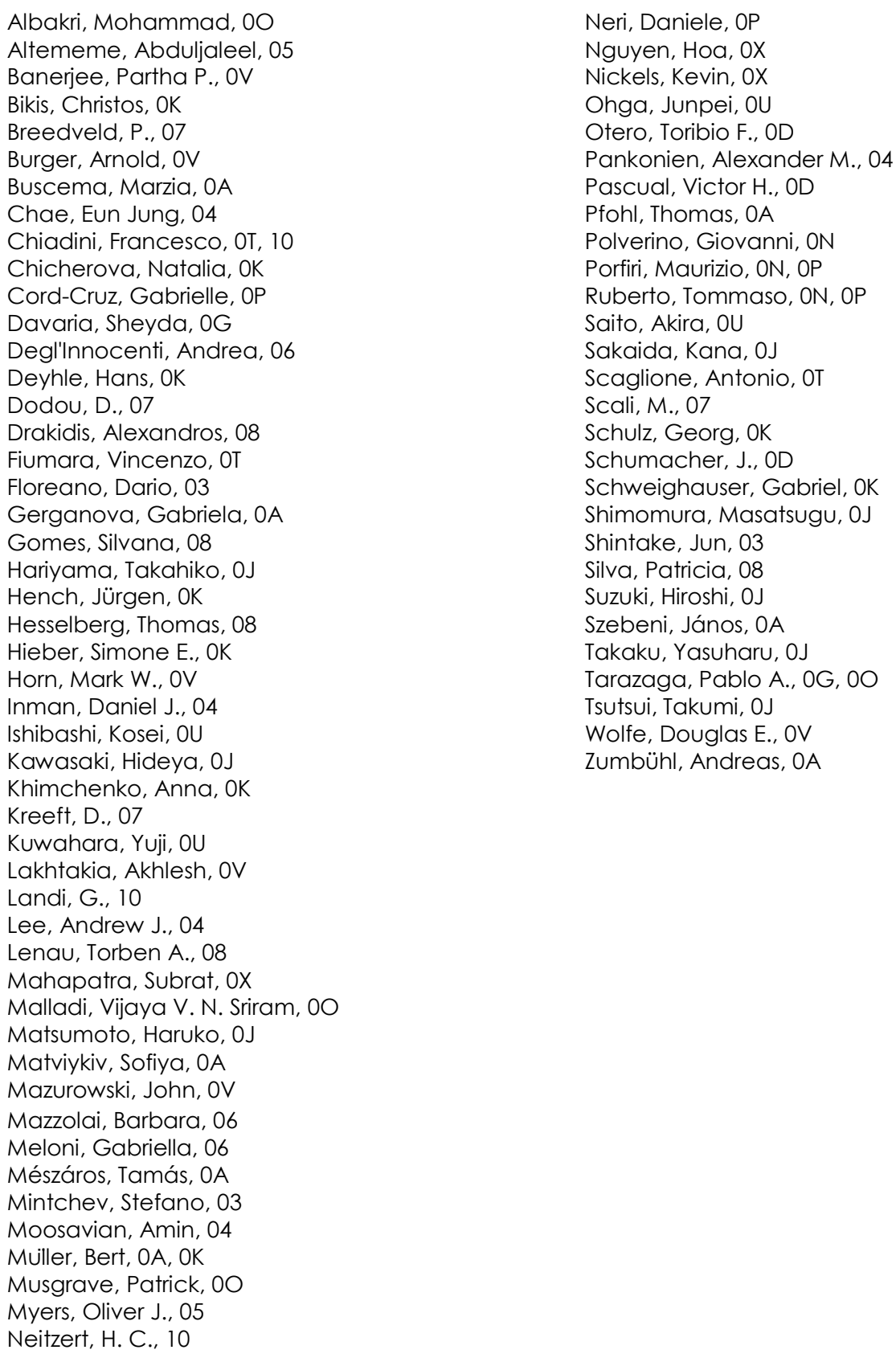

Neri, Daniele, OP

Nguyen, Hoa, OX

Nickels, Kevin, OX

Ohga, Junpei, OU

Otero, Toribio F., OD

Pankonien, Alexander M., 04

Pascual, Victor H., OD

Pfohl, Thomas, OA

Polverino, Giovanni, ON

Porfiri, Maurizio, ON, OP

Ruberto, Tommaso, ON, OP

Saito, Akira, OU

Sakaida, Kana, 0J

Scaglione, Antonio, OT

Scali, M., 07

Schulz, Georg, OK

Schumacher, J., OD

Schweighauser, Gabriel, OK

Shimomura, Masatsugu, OJ

Shintake, Jun, 03

Silva, Patricia, 08

Suzuki, Hiroshi, OJ

Szebeni, János, OA

Takaku, Yasuharu, 0J

Tarazaga, Pablo A., 0G, 00

Tsutsui, Takumi, 0J

Wolfe, Douglas E., OV

Zumbühl, Andreas, OA 
Proc. of SPIE Vol. 10162 1016201-6

Downloaded From: https://www.spiedigitallibrary.org/conference-proceedings-of-spie on 26 Apr 2023 Terms of Use: https://www.spiedigitallibrary.org/terms-of-use 


\title{
Conference Committee
}

\author{
Symposium Chairs \\ Jayanth N. Kudva, NextGen Aeronautics, Inc. (United States) \\ Theodoros E. Matikas, University of loannina (Greece) \\ Symposium Co-chairs \\ Tribikram Kundu, The University of Arizona (United States) \\ Gregory W. Reich, Air Force Research Laboratory (United States) \\ Conference Chair \\ Mato Knez, CIC nanoGUNE Consolider (Spain) \\ Conference Co-chairs
}

Akhlesh Lakhtakia, The Pennsylvania State University (United States)

Raúl J. Martín-Palma, Universidad Autónoma de Madrid (Spain)

Conference Program Committee

Javaan S. Chahl, University of South Australia (Australia)

Francesco Chiadini, Università degli Studi di Salerno (Italy)

Carolyn Dry, Natural Process Design, Inc. (United States)

Olaf Karthaus, Chitose Institute of Science and Technology (Japan)

Mathias Kolle, Massachusetts Institute of Technology (United States)

Kostya Kornev, Clemson University (United States)

Bert Müller, Basel Universität Hospital (Switzerland)

Akira Saito, Osaka University (Japan)

Kathleen Stebe, University of Pennsylvania (United States)

Eric J. Warrant, Lund Universitet (Sweden)

Cordt Zollfrank, Technische Universität München (Germany)

\section{Session Chairs}

1 Flight

Mato Knez, CIC nanoGUNE Consolider (Spain)

2 Mechanobiology and Drug Delivery

Akhlesh Lakhtakia, The Pennsylvania State University (United States)

3 Materials

Hendrik Holscher, Karlsruher Institut für Technologie (Germany) 
4 Characterization

Bert Müller, Universität Basel (Switzerland)

5 Mechanisms and Models

Akira Saito, Osaka University (Japan)

6 Functional Surfaces

Andrea Degl"Innocenti, Istituto Italiano di Tecnologia (Italy) 